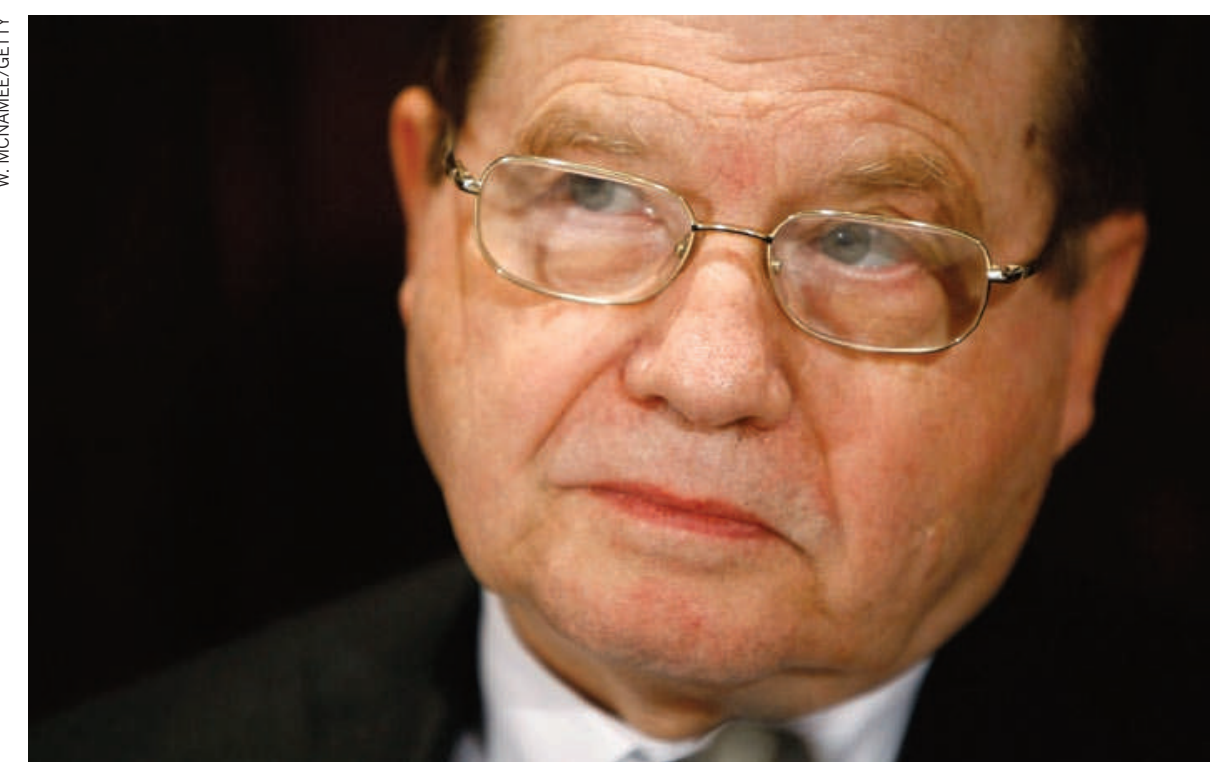

Luc Montagnier, co-discoverer of HIV, is no stranger to controversy.

\title{
MEDICINE
}

\section{Trial draws fire}

\section{Nobel laureate to test link between autism and infection.}

\section{BY DECLAN BUTLER}

$\mathrm{L}$ uc Montagnier is applying unorthodox ideas to the treatment of autism. With support from the Autism Research Institute (ARI), based in San Diego, California, the Nobel laureate is about to launch a small clinical trial of prolonged antibiotic treatment in children with autism disorders. The trial will also use techniques based on Montagnier's research into the notion that water can retain a 'memory' of long-vanished pathogens, and that DNA sequences produce water nanostructures that emit electromagnetic waves, published last year. But experts are critical and worry that the nobelist's status may lend unwarranted credibility to unconventional approaches to autism.

The planned pilot trial in France - funded by a US $\$ 40,000$ grant from ARI - will screen around 30 children with autism disorders and 20 or so controls for bacterial infections, and then test whether months of antibiotic treatment improve the children's condition. Montagnier, who shared the 2008 Nobel prize for physiology or medicine for the discovery of $\mathrm{HIV}$, concedes that there is no solid scientific evidence that infection causes or contributes to autism, but he argues that many parents and physicians have observed "spectacular" benefits from prolonged treatment. Stephen Edelson, director of ARI, says he's "very excited" about the "cutting-edge, groundbreaking" study.

Catherine Lord, a clinical psychologist working on autism at the University of Michigan in

Ann Arbor, says that the trials are "not mainstream science". Lord says that many of the widely practised alternative medicine treatments for autism - including dietary modification, nutritional supplements and chelation therapy — are "semi-medical, not evidencebased science, and more pseudoscience."

Edelson, however, says that there are so many forms of autism and so much that is not known that "we need to study every angle". Criticisms of the science base of alternative approaches "probably would have been true were it ten years ago", he says, but critics don't appreciate how much research has been done since.

"I'm just interested in helping these children," Montagnier says. He acknowledges that many mainstream scientists are sceptical of his work, but defends his ideas. "In 1983, we were only a dozen or so people to believe that the virus we had isolated was the cause of AIDS."

Since then, Montagnier has supported nonmainstream theories in AIDS research that have put him at odds with other scientists. Most recently, he has argued that strengthening the immune system with antioxidants and nutritional supplements needs to be considered along with antiretroviral drugs in fighting AIDS, in particular in Africa.

D NATURE.COM For more on Nobel laureates' views on science see: go.nature.com/fmmdne
“Montagnier's embrace of pseudoscientific and fringe agendas over the past few years has been seized on by AIDS denialists and other fringe

groups, who make the case that Montagnier now supports their crazy views," says John Moore, an AIDS virologist at Cornell University in New York. Montagnier says that AIDS denialist groups misrepresent his thinking.

The autism trial enters a new area of controversy. The Infectious Disease Society of America have reviewed long-duration antibiotic treatments in Lyme disease, and concluded in April that the "inherent risks of long-term antibiotic therapy were not justified by clinical benefit". Montagnier acknowledges that safety concerns exist, but argues that opposition to long antibiotic treatments can also be "dogma". The trials will need to be cleared with the relevant ethics and regulatory bodies, he notes, and will include careful precautions and surveillance. "Expert physicians have learned to avoid side effects and to choose the right regimen," he says.

Another element of the trial is also attracting scepticism. Besides screening the children for pathogens with conventional DNA-amplification techniques, the researchers will use a diagnostic test based on the controversial idea championed by the late French scientist Jacques Benveniste, who claimed that water can retain the memory of substances it contained even after they have been diluted away. Studies have failed to confirm the claim, but Montagnier thinks that the 'memory' structures in the water can resonate with low-frequency electromagnetic signals, which he hopes can be transmitted over the Internet. He claims that very dilute solutions of pathogen DNA also emit such signals, and he intends to use this as a sensitive 'biomarker' for chronic infection.

Montagnier has published two papers on his research into the memory of water, one on bacterial DNA (ref. 1) and another claiming to have found electromagnetic signals of HIV DNA (ref. 2) in patients treated with antiretroviral drugs

“I'mjust interested in helping these children." \section{antiretroviral treatment} is paused or stopped. Several AIDS researchers contacted by Nature dismissed Montagnier's claims but declined to comment publicly.

Montagnier, who says that he is planning independent replication of his findings, published both papers in a new journal from Berlin-based Springer - Interdisciplinary Sciences: Computational Life Sciences, the editorial board of which he chairs. Asked why he didn't try to publish his astonishing findings in a higherprofile journal, Montagnier explained that he was sure that if he had sent them to Nature or Science, he would have run foul of experts who, on seeing mention of Benveniste or 'memoryof-water, would "reach for their revolvers".

1. Montagnier, L. et al. Interdisciplin. Sci.: Comput. Life Sci. 1, 81-90 (2009)

2. Montagnier, L. et al. Interdisciplin. Sci.: Comput. Life Sci. 1, 245-253 (2009). 